Vol. 4, No. 2, 2019

\title{
SOCIO-PSYCHOLOGICAL ESSENCE OF ATTRACTIVENESS FOR THE SUBJECTS OF ENTREPRENEURIAL ACTIVITIES OF ADSORPTION EXTRACTION OF NICKEL IONS (II) BY BENTONITE CLAYS
}

\author{
Halyna Sakalova ${ }^{1}$, Olha Palamarchuk ${ }^{1}$, Tamara Vasylinycz ${ }^{1}$, Kateryna Petrushka ${ }^{2}$, \\ Jaroslava Zaharko ${ }^{2}$, Oleh Stocaluk ${ }^{3}$ \\ ${ }^{1}$ Vinnytsia State Pedagogical University named after Mykhailo Kotsiubynsky \\ 32, Ostrozhskogo Str., Vinnytsia, 21100, Ukraine \\ ${ }^{2}$ Lviv Polytechnic National University, \\ 12, S. Bandery Str., Lviv, 79013, Ukraine \\ ${ }^{3}$ Lviv State University of Life Safety, \\ 35, Kleparivska Str., Lviv, 79007, Ukraine \\ sakalovag@gmail.com
}

https://doi.org/10.23939/ep2019.02.068

Received: 10.03 .2019

(C) Sakalova H., Palamarchuk O., Vasylinycz T., Petrushka K., Zaharko Ja., Stocaluk O., 2019

\begin{abstract}
The article considers an actual but not sufficiently developed problem of attractiveness for the subjects of entrepreneurial activity of adsorption extraction of Nickel ions (II) by bentonite clays. The basic social and psychological mechanisms for the adoption of environmentally-oriented activities are analyzed. The styles of entrepreneurs' response to the attractiveness of adsorption extraction of Nickel ions (II) by bentonite clays are characterized. The process of sorption of Nickel ions (II) with a fixed layer of sorbent by bentonite clays is investigated. The main advantages of using bentonites in water treatment technologies are described: powerful geological reserves, cheap rock formation, simple preparation for transportation and use, the possibility of using spent sorbents in other technologies, eliminating the need for expensive regeneration. The influence of different factors (length of the process, layer of the adsorbent) on the degree of wastewater treatment from Nickel ions, influence of pumping speed on dynamic capacity of the sorbent is investigated and effective volume is determined.

The results of the research indicate that the use of natural mineral sorbents, in particular, the bentonite clay of Cherkassy deposit, is promising and effective for purification of waste water from Nickel (II) ions.
\end{abstract}

Key words: ecological safety, natural clay sorbents, adsorption, ions of heavy metals.

\section{Introduction}

In the field of the analysis of the economic and ecological component of transformational changes in Ukraine, the study of attractiveness for the subjects of entrepreneurial activity of adsorption extraction of Nickel ions (II) by bentonite clays is becoming particularly relevant. An analysis of the sociopsychological characteristics of entrepreneurs allows us to distinguish the response styles to the attractiveness of using adsorption extraction of Nickel ions (II) by bentonite clays. The basis for distinguishing the response styles to the attractiveness of adsorption extraction of Nickel ions (II) by bentonite clays is made up by social and psychological mechanisms: negation, that is, negative attitude toward adsorption extraction of ions $\mathrm{Ni}^{2+}$ by bentonite clays; experience, that is, shifting the emphasis on individual difficulties in the use of adsorption extraction of nickel ions by bentonite clays; reasoning which manifests in the attitude to adsorption extraction of Nickel (II) ions by bentonite clays as to the necessity, cognitive acceptance of such activity; acceptance which is expressed in positive attitude to adsorption extraction of Nickel ions (II) bentonite clays, establishment of the automatic search for the advantages and benefits of such activity.

This approach makes it possible to assume the existence of four styles of entrepreneurs' response to the attractiveness of adsorption extraction of $\mathrm{Ni}^{2+}$ ions by 
bentonite clays: innovative, conservative, reactive and realizing. Entrepreneurs, who have an innovative style, easily take the opportunity to use adsorption extraction of Nickel ions (II) by bentonite clays. They are emotionally involved in new environmentally-friendly initiatives [1]. Entrepreneurs with conservative style rarely see the need to use the technology of adsorption extraction of Nickel ions (II) bentonite clays. Environmentally-oriented activities make them experience more negative emotions rather than positive ones. The reactive style is typical for entrepreneurs who react to the possibility of using adsorption extraction of $\mathrm{Ni}^{2+}$ ions by bentonite clays emotionally and prefer stability to innovation. In order to make them accept the technology of adsorption extraction of Nickel ions (II) by bentonite clays, it is necessary to show them the personal benefit of it, empathize with them because of the need to accept such technology, and help them to overcome stress and discomfort. Entrepreneurs with implementing style support the technology and are involved in the possibility of using the technology of adsorption extraction of Nickel ions (II) by bentonite clays.

Consequently, the concept of the attractiveness of environmental orientation in the modern way of life of business entities should be based on the values of environmentally innovative entrepreneurial activity and understanding that pollution of sewage and surface water by heavy metal ions is one of the serious environmental problems that still has not been solved effectively enough. Therefore, it is important to improve the existing and search for new methods, materials and technologies for water purification, which will minimize the inflow of heavy metal ions into the hydrosphere.

Subjects of entrepreneurial activities should understand that wastewater of galvanic production containing toxic ions of heavy metals, in particular $\mathrm{Ni}^{2+}$ ions, is very dangerous for water objects of Ukraine. Among the methods that should be successfully applied to reduce the content of heavy metals in wastewater, a sorption method is one of the most effective. The use of active sorbents makes it possible to thoroughly clean up wastewater, which contains even minor concentrations of these metals, while other methods are not effective.
Sorbents of natural origin: clay rocks, apatites, zeolites are increasingly used for water purification. The use of such sorbents is due to their fairly high sorption capacity, cation exchange properties of some of them, relatively low cost and availability. The advantages of the sorption method include the possibility of removing contamination of an extremely wide nature to virtually any concentration, the absence of side contamination and controllability of the process.

There are many deposits in Ukraine with multimillion reserves of various effective sorbents. These are, first of all, clay materials: montmorillonites and their varieties saponite, natronit, sokolit and other clays such as bentonite, kaolin, paligorskita. Entrepreneurs are simply obliged to know the main advantages of the use of adsorption materials:

- natural sorbents are widespread in Ukraine;

- natural sorbents are affordable, inexpensive material;

- adsorption technologies using natural disperse sorbents provide a high degree of purification;

- the spent natural adsorbent must be disposed by being used in the technology of obtaining other products, it does not require regeneration.

When it comes to using bentonite in sorbent water purification technologies, the main advantages of this sorbent are high sorption capacity, mechanical strength and low price. Sorbent can be used in systems of city water channels, at water intakes instead of traditional river sand, in systems of water purification from radionuclides.

There are over 110 deposits and manifestations of bentonites in Ukraine. The state balance of Ukraine's reserves includes 6 deposits (Gorbkivske, Kudrinske, Cherkassy, Kurtsivske, Berezhany, Pyzhivske). Their stocks are classified by categories A + B + C1 - 60624 thousand tons, $\mathrm{C} 2-221$ thousand tons; balanced reserves - by the categories $\mathrm{B}+\mathrm{C} 1+\mathrm{C} 2$ amount to 1.415 thousand tons. In recent years, the situation with the extraction of bentonite clay in the country has improved (Table 1). The internal need for bentonite clay is completely satisfied at the expense of extraction of bentonites from their own deposits.

Table 1

Extraction of bentonite clay in Ukraine (2003-2011)

\begin{tabular}{|c|c|c|c|c|c|c|c|c|c|}
\hline Year of extraction & 2003 & 2004 & 2005 & 2006 & 2007 & 2008 & 2009 & 2010 & 2011 \\
\hline (thousand tons) & 64 & 51 & 65 & 142 & 122 & 127 & 145 & 139 & 162 \\
\hline
\end{tabular}

The mineral and raw material base of bentonite clays in Ukraine is characterized by a significant amount of previously explored reserves and promising resources which were investigated in certain periods in accordance with various requirements for geological and technical and economic study of objects. As a result, the formed 
information base requires the systematization of the data obtained and evaluation according to the common geological and economic criteria.

According to the mineral composition, three types of bentonite clay are distinguished [2]. The first type is clay of montmorillonite composition. Clays of this type are distributed mainly in the Autonomous Republic of Crimea (Kurtsivske and Kudrinske deposits), Khmelnytskyi region (Pyzhiv deposit). The second type is the clay of the beidelite-montmorillonite composition. Clays of this type are common in the Cherkasy (Cherkasy deposit) and Ternopil (Berezhansky deposit) regions. The third type includes clays of montmorillonite-beidelite composition. Clays of this type are distributed in the Khmelnytsky, Ternopil and Donetsk regions.

\section{Setting the task and its solution}

The purpose of the work is to study the attractiveness of the process of purifying wastewater from Nickel ions (II) by adsorption on natural sorbents for business entities. Investigation of the adsorption process was carried out in an adsorption column with a stationary layer of the adsorbent.

For the studies, bentonite (type 2: 1) from the Cherkasy deposit of bentonite and paligorskite clays was used. The process of preparing bentonite consisted of several stages. The raw material was ground and dried in a drying chamber at a temperature of $120{ }^{\circ} \mathrm{C}$ for 45 minutes. After that, the clay was triturated and separated into appropriate fractions.

To obtain modified bentonite, a $200 \mathrm{~g}$ weight of natural clay has been treated with $1 \mathrm{~N}$ solution of chloride acid (volume $\mathrm{V}=0.6 \mathrm{dm}^{3}$ ) for 24 hours. The mother liquor was decanted, the sample was washed with hot distilled water to neutralize the methylorange; dried in a drying cabinet at a temperature of $120{ }^{\circ} \mathrm{C}$ to a constant mass, and then cooled in the desiccator [3].

Studies of the sorption of nickel were carried out by the method of individual stresses. Pre-prepared model solution was dissolved in water $\mathrm{NiSO}_{4} \cdot 7 \mathrm{H}_{2} \mathrm{O}$ with concentration of nickel ions of $0.5 \div 2.5 \mathrm{~g} / \mathrm{dm}^{3}$. Studies of the sorption of nickel were carried out by the method of individual stresses. During the experiments, such parameters as the adsorbent layer and the velocity of pump modeling were varied.

Water purification was carried out on a laboratory adsorption column, which has a diameter of $35 \mathrm{~mm}$ and a height of $600 \mathrm{~mm}$, using bentonite clay. Prepared clay was filled into a column. The total mass of the sorbent in the adsorption column was $15 \div 25 \mathrm{~g}$. The volume of the sorbent in the column was $21.6 \mathrm{ml}$ and $29 \mathrm{ml}$, respectively, with a mass of sorbent of 15 and $20 \mathrm{~g}$.

The solutions containing $\mathrm{Ni}^{2+}$ ions of given concentrations were passed through the column. The samples were sorted every $10 \mathrm{dm}^{3}$; the concentration of $\mathrm{Ni}^{2+}$ ions in the solution was determined by the titrimetric method [3].

\section{Results and Discussion}

To establish the range of regime parameters for which a detailed study of adsorption processes is necessary, a series of previous experiments was performed, which made it possible to make the following preliminary conclusions:

1. Temperature fluctuations from +10 to $+30{ }^{\circ} \mathrm{C}$ do not show a noticeable influence on the level of adsorption of ions by $\mathrm{Ni}^{2+}$ bentonite.

2. The optimum ratio is between $1: 20$ of solid and liquid phases; at a higher dilution, the amount of adsorbed $\mathrm{N}^{2+}$ decreases, and a lower $\mathrm{T}$ : $\mathrm{P}$ ratio, despite the improvement in the adsorption results, is irrational, since already at $\mathrm{T}: \mathrm{P}=1: 7$ there is a strong thickening of the pulp, which complicates further filtration processes.

3 . The range of investigated concentrations $\left(0.5 \div 2.5 \mathrm{~g} / \mathrm{dm}^{3}\right)$ of nickel ions was chosen based on practical considerations according to the possible content of $\mathrm{Ni}^{2+}$ cation of real drains.

It has been pre-established that the full saturation of bentonite clay with the $\mathrm{Ni}^{2+}$ ions is achieved with a $15 \div 20 \mathrm{~g}$ layer of the adsorbent, and a pumping rate of $0,005-0,01 \mathrm{dm}^{3} / \mathrm{s}$ for $4 \div 6$ hours.

4. Dynamic exchange capacity of materials was determined as the amount of absorbed Nickel ions (II) until the detection of the first traces of ions $\mathrm{N}^{2+}$ at the output of the column is attributed to the mass of the ionexchange material.

For calculation we used formula 1:

$$
\mathrm{T}=\frac{\mathrm{q}}{\mathrm{m}},
$$

where $\mathrm{q}$ - amount of absorbed contamination (ions $\left.\mathrm{Ni}^{2+}\right), \mathrm{g} ; \mathrm{m}-$ mass of clay, $\mathrm{g}$.

Effective volume $\left(\mathrm{V}_{\text {eff }}\right)$ is calculated by the formula 2 :

$$
\mathrm{V}_{\mathrm{eff}}=\frac{\mathrm{V}_{\text {solution }}}{\mathrm{V}_{\text {column }}} \text {. }
$$

The value as well as the value of $\mathrm{T}$ is dimensionless. Very often, for the best perception values $V_{\text {eff }}$ are represented in units of $\mathrm{OK}$ - column volume.

The results of all cycles of saturation of bentonite are given in Table 2 [5]. 
Results of all cycles of saturation of bentonite

\begin{tabular}{|c|c|c|c|c|c|c|}
\hline № & $\begin{array}{l}\text { Time } \\
(\rightarrow), \min \end{array}$ & $\begin{array}{c}\mathrm{C}_{0} \\
\left(\mathrm{Ni}^{2+}\right) \mathrm{g} / \mathrm{dm}^{3}\end{array}$ & $\begin{array}{c}\text { Effective volume } \\
\qquad\left(\mathrm{V}_{\text {eff }}\right)\end{array}$ & $\begin{array}{l}\text { First traces } \mathrm{Ni}^{2+} \text { in } \\
\text { purified water, min }\end{array}$ & $\begin{array}{c}\text { Dynamic exchange } \\
\text { capacity }(\mathrm{T})\end{array}$ & $\alpha, \%$ \\
\hline \multicolumn{7}{|c|}{ Mass of sorbent $15 \mathrm{~g}$} \\
\hline 1 & 320 & 0.5 & 8.32 & 104 & 44.76 & 46.9 \\
\hline 2 & 315 & 1 & 6.93 & 110 & 47.05 & 43.5 \\
\hline 3 & 325 & 1.5 & 6 & 115 & 56.03 & 35.7 \\
\hline 4 & 330 & 2 & 4.62 & 120 & 52.9 & 32.6 \\
\hline 5 & 345 & 2.5 & 2.77 & 123 & 53.21 & 26.4 \\
\hline \multicolumn{7}{|c|}{ Mass of sorbent $20 \mathrm{~g}$} \\
\hline 6 & 460 & 0.5 & 6.93 & 109 & 36.91 & 53.3 \\
\hline 7 & 468 & 1 & 5.89 & 115 & 34.38 & 50.5 \\
\hline 8 & 470 & 1.5 & 5.2 & 120 & 40.07 & 45 \\
\hline 9 & 492 & 2 & 4.16 & 130 & 38.36 & 34 \\
\hline 10 & 521 & 2.5 & 3.4 & 145 & 45.41 & 29.3 \\
\hline
\end{tabular}

According to the results of the experiment, the maximum absorption of Nickel ions (II) occurs with a sorbent layer of $20 \mathrm{~g}$ of the initial concentration of nickel ions of $0.5 \mathrm{~g} / \mathrm{dm}^{3}$ and is $53.3 \%$. The effectiveness of adsorption increases with increase in the layer of adsorbent, which can be explained by the development of the active sorption surface. The largest effective volume for pumped model solution through the absorbent layer of $15 \mathrm{~g}$ is 8.32 , and at the passage of $200 \mathrm{dm}^{3}$ through $20 \mathrm{~g}$ of the sorbent it is 6.93. These values are observed in both cases for model solutions with the smallest concentration of heavy metal ion, which suggests that the use of bentonite as an adsorbent for the removal of Nickel ions from aqueous solutions is expedient and effective in the processes of pretreatment. Also, with the increase in the initial concentration of Nickel ions, the time of appearance of the first traces of the pollutant at the exit of the column increases, as well as the total time before the breakthrough.

The results of the saturation of natural bentonite from the model solutions found in Nickel ions is presented in Fig. 1 and 2.

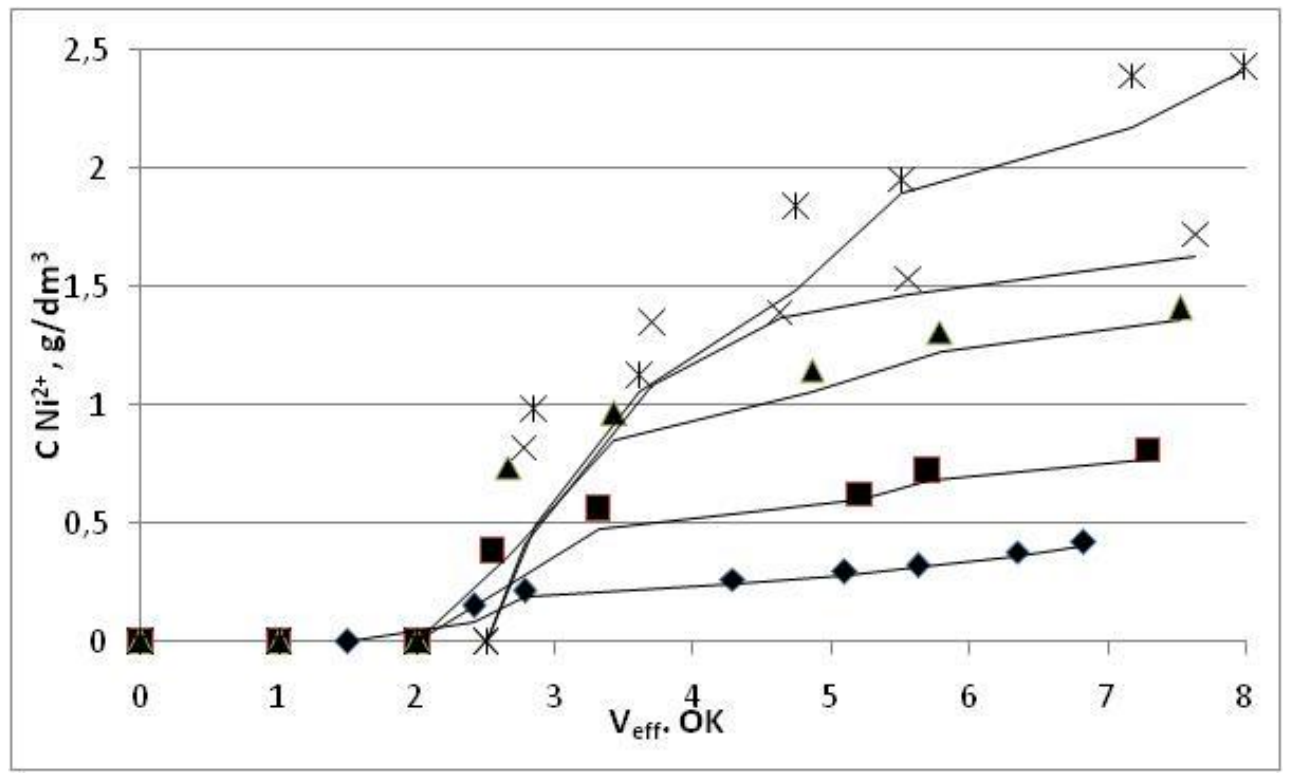

Fig. 1. Saturation curves of bentonite weighing $15 \mathrm{~g}$ with model solution with initial concentration of $\mathrm{Ni}^{2+}, \mathrm{g} / \mathrm{dm}^{3}:-0,5 ; \mathbf{a}-1 ; \mathbf{\Delta}-1,5 ; \mathrm{x}-2 ; \quad \mathcal{X}-2,5$ 


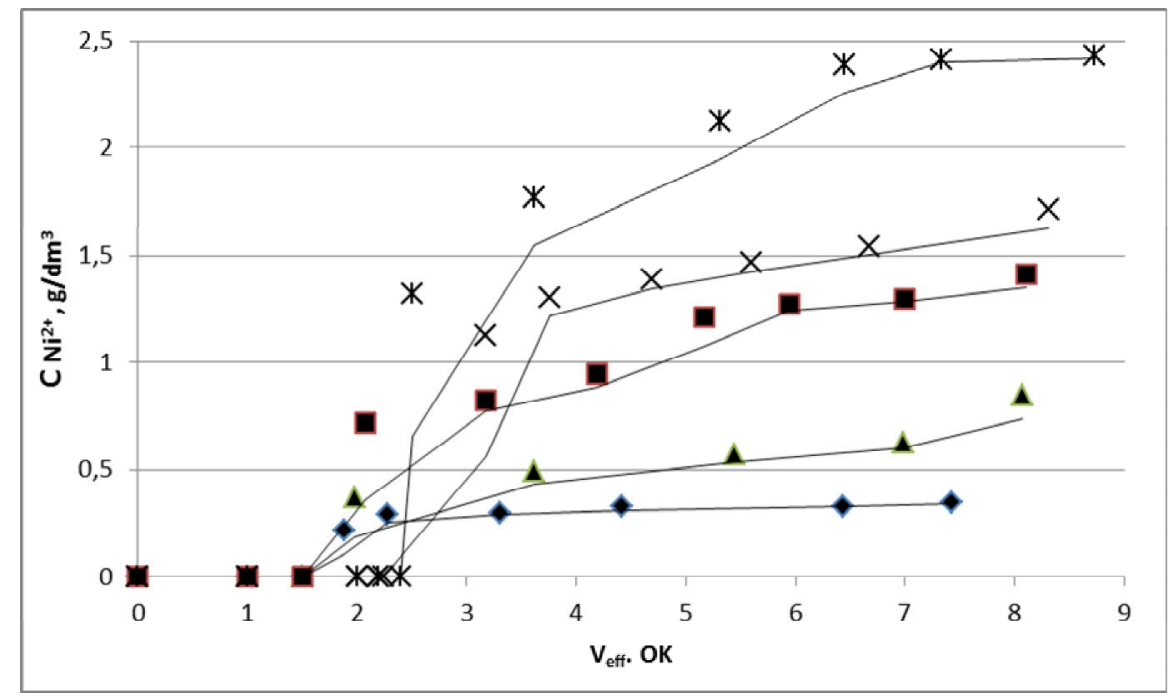

Fig. 2. Saturation curves of bentonite weighing $20 \mathrm{~g}$ with model solution with initial concentration of $\mathrm{Ni}^{2+}, \mathrm{g} / \mathrm{dm}^{3}:-0,5 ; \mathbf{-}-1 ; \boldsymbol{\Delta}-1,5 ; \mathbf{x}-2 ;$ K $-2,5$

As shown by the curves of bentonite saturation with Nickel ions, presented in the form of dependence of the concentration of heavy metal ion at the exit of the column $\left(\mathrm{C}_{\text {eff }}\right)$ on the volume of pumped solutions $\left(\mathrm{V}_{\mathrm{eff}}\right)$, the concentration of the model solution has a significant effect on the process of saturation. At different costs of bentonite a fuller use of the adsorption capacity of the material can be achieved at lower concentrations. However, the gain in the larger dynamic exchange capacity is small compared with the difference between the consumption of the adsorbent. The first traces of Nickel ions at the exit of the column were detected after pumping 1.5-2.3 OK of the model solution through $15 \mathrm{~g}$ of bentonite, and when using $20 \mathrm{~g}$, the first traces were determined in volumes of 1.8-2.6 OK which corresponds to the difference in the dynamic exchange capacity of $7.85 \div 6.4$.

When using modified bentonite, the saturation curves indicate similar dependencies: the adsorption capacity of bentonite is higher in the case of using smaller concentrations of the initial solution, and in the case of using $20 \mathrm{~g}$ of adsorbent, the purification efficiency is higher. The time intervals for control measurements are very close, which is also evidenced by similar values of the indicator of effective volume (Table 3).

\section{Results of saturation of modified betonies with nickel ions}

\begin{tabular}{|c|c|c|c|c|c|c|}
\hline № & $\begin{array}{l}\text { Time } \\
(\rightarrow), \min \end{array}$ & $\begin{array}{c}\mathrm{C}_{0} \\
\left(\mathrm{Ni}^{2+}\right)\end{array}$ & $\begin{array}{l}\text { Effective volume } \\
\qquad\left(\mathrm{V}_{\text {eff }}\right)\end{array}$ & $\begin{array}{l}\text { First traces } \mathrm{Ni}^{2+} \text { in } \\
\text { purified water, min }\end{array}$ & $\begin{array}{c}\text { Dynamic exchange } \\
\text { capacity }(\mathrm{T})\end{array}$ & $\alpha, \%$ \\
\hline \multicolumn{7}{|c|}{ Mass of sorbent $15 \mathrm{~g}$} \\
\hline 1 & 318 & 0.5 & 8.58 & 105 & 60.12 & 63.0 \\
\hline 2 & 319 & 1 & 6.98 & 108 & 62.19 & 57.5 \\
\hline 3 & 329 & 1.5 & 6.2 & 115 & 72.7 & 52.8 \\
\hline 4 & 335 & 2 & 4.69 & 123 & 75.78 & 46.7 \\
\hline 5 & 349 & 2.5 & 2.88 & 125 & 79.4 & 39.4 \\
\hline \multicolumn{7}{|c|}{ Mass of sorbent $20 \mathrm{~g}$} \\
\hline 6 & 462 & 0.5 & 6.98 & 108 & 50.75 & 73.4 \\
\hline 7 & 467 & 1 & 5.94 & 113 & 59.43 & 63.8 \\
\hline 8 & 473 & 1.5 & 5.28 & 122 & 49.07 & 55.8 \\
\hline 9 & 495 & 2 & 4.46 & 134 & 60.02 & 53.2 \\
\hline 10 & 525 & 2.5 & 3.48 & 149 & 70.21 & 45.3 \\
\hline
\end{tabular}


The results of the studies indicate a higher adsorption capacity of modified bentonite in relation to nickel ions compared with its natural form. As the results of the experiment show that the maximum absorption of Nickel (II) ions in modified bentonite occurs at a layer of sorbent of $20 \mathrm{~g}$ for 4.5 hours and is $73.4 \%$.

\section{Conclusions}

The conducted studies confirmed the promising use of bentonite clay for purification of waste water from nickel ions (II) by adsorption with a fixed layer of sorbent in the activity of modern business entities. The effectiveness of adsorption increases with the increase in the layer of the adsorbent, which can be explained by the development of active sorption surface. The use of a modified sorbent allows business entities to achieve a higher degree of purification of solutions with a concentration of nickel ions of $0.5 \div 2.5 \mathrm{~g} / \mathrm{dm}^{3}$.

As the initial concentration of nickel ions increases, the time of appearance of the first traces of pollution at the exit of the column increases too, as well as the total time before the breakthrough. The highest degree of purification is observed for model solutions with the lowest concentration of heavy metal ion $\left(0.5 \mathrm{~g} / \mathrm{dm}^{3}\right)$, which suggests that the use of bentonite as an adsorbent for the removal of nickel ions from aqueous solutions is expedient and effective in the processes of pretreatment.

\section{References}

[1] Palamarchuk O. M. Social no-psyxologichni osobly`vosti proyavu ekologizaciyi na riznyx etapax rozvy`tku suspil`stva. Aktual`ni problemy` psyxologiyi : zb. nauk. pr. In-tu psy`xologiyi imeni G. S. Kostyuka NAPN Ukrayiny`. - Zhytomy`r : Vyd-vo ZhDU im. I. Franka. 2012. T. 7 : Ekologichna psy`xologiya, vy`p. 29. S. 349-358.

[2] Palamarchuk O. M. Ekologichna oriyentaciya v suchasnomu sposobi zhy`ttya sub'yektiv pidpry`yemny`cz`koyi diyal`nosti. Aktual’ni problemy` psy`xologiyi : zb. nauk. pr. In-tu psy`xologiyi imeni G. S. Kostyuka NAPN Ukrayiny`. - Zhy`tomy`r : Vy`d-vo ZhDU im. I. Franka. 2013. T. 7 : Ekologichna psy`xologiya, vy`p. 33. S. 378-387.

[3] Sakalova G. V., Vasylinycz T. M., Koval N. O., Kashchei V. A. Investigation of the metod of chemical desorption for exstraction of nikel ions (II) from bentonite clays. Enviromental problems. 2017. No. 4, Vol. 2. P. 187-190.

[4] Odnorig Z. S. Sorbciya ioniv midi ximichno mody`fikovany`m pry`rodny`m kly`nopty`lolitom: dy`s. kand. texn. nauk: 05.17.08 / Nacional`ny`j universy`tet "L`vivs`ka politexnika", L`viv: 2002. 118 s.

[5] Lucevy`ch D. D. Anality`chna ximiya: pidruchny`k / D. D. Lucevy`ch, A. S. Moroz, O. V. Gry`bal`s`ka. K.: Medy`cy`na, 2009. $416 \mathrm{~s}$.

[6] Onofrijchuk N. V. Mal’ovany`j M. S., Vasy`liny`ch T. M., Sakalova G. V., Perspekty`vy` zastosuvannya bentonitovy`x gly`n pry`ochy`shhenni stichny`x vod vid ioniv vazhky`x metaliv. Zbirny`k materialiv V Vseukrayins`kogo z'yizdu ekologiv z mizhnarodnoyu uchastyu (Ekologiya /Ecology - 2017), Vinny`cya: VNTU, 2017. S. 78. 